International Journal of Biology, Pharmaey and Allied Sciences (IJBPAS)

'A Bridge Betuen Caboratory and Q Qender'

wWw.ijbpas.com

\title{
A REVIEW ON DIFFERENT PARTS OF THE PLANT CITRULLUS COLOCYNTHIS SCHRAD AND THEIR ANTIDIABETIC POTENTIAL
}

\author{
SHAIKH M.T ${ }^{* 1}$, JAT R. ${ }^{2}$, ANSARI Y.A. ${ }^{3}$, BAND A.A. ${ }^{4}$, KHAN R.A. ${ }^{5}$ \\ 1, 3, 4, 5: Jamia College of Pharmacy, Akkalkuwa, Dist. Nandurbar-425415, Maharashtra, India \\ 2: Shri JJT University, Vidyanagari, Jhunjhunu, Rajasthan, Pin code -333001 \\ *Corresponding Author: Shaikh Mohammed Tariq: E Mail: tariqanytime@gmail.com; Telephone \\ Number: +91- 8149345492 \\ Received $16^{\text {th }}$ April 2020; Revised $6^{\text {th }}$ May 2020; Accepted $8^{\text {th }}$ June 2020; Available online $1^{\text {st }}$ Dec. 2020 \\ https://doi.org/10.31032/IJBPAS/2020/9.12.5282
}

\begin{abstract}
Diabetes is a major evildoer behind the mortality in the world. Worldwide data on mortality, Prevalence, and Incidence demand the humankind to take genuine endeavors on this issue, Current investigations and statics have expounded diabetes as one of the most prevalent endocrine disorder throughout the world. Citrullus colocynthis Schrad (CCS) is one of the most widely recognized conventional plants utilized as a remedy against diabetes. It is well recognized by its hypoglycaemic effect, which is substantiated. This plant, the fruit is usually recognized for its wide scope of anti-diabetic uses as well as pharmaceutical and nutraceutical potential. A genuine effort without any bias and interest has been taken in this article which provides the clear and cosine worldwide clinical and regulatory data of CCS. This review also sums up the various proven antidiabetic potential of $C C S$ along with the granted patents. The only objective behind this article is to provide a thought process and to give a new vision to present and future scientists, researchers, industries, and regulatory bodies on the potential of $C C S$ in diabetes for the betterment of society by highlighting clinical and pre-clinical studies which contributed to support the concept. This paper concludes that CCS possesses a wide range of medicinal uses and has been well studied for its antidiabetic potential.
\end{abstract}

Keywords: Citrullus colocynthis Schrad, Clinical Trials, Diabetes, Medicinal Parts, Patents, Herbal 


\section{INTRODUCTION}

Out of many endocrinal diseases, diabetes is one of the most commonly prevalent metabolic disorders which distresses over one billion population of the world and cause extensive deaths. Various factors causing this disease have been observed, including diet and age [1]. World Health Organization (WHO) has revealed that three billion diabetic cases would be observed by the year 2025 [2]. As per WHO diabetes is one of the main culprits of death in the world and around 422 million individuals worldwide have diabetes, especially in low-and center pay nations $[3,4]$. The American Diabetes Association gave insights about diabetes and proposed to make a move against prediabetes few changes in diet and exercise that can have a major effect with prediabetes $[5,6]$. Centre for disease control and prevention, 2020 national report estimated excess of 88 million US grown-ups-over a third-have prediabetes, and over $80 \%$ of them don't realize they have it and diabetes is the seventh driving reason for death in the United States [7-9].

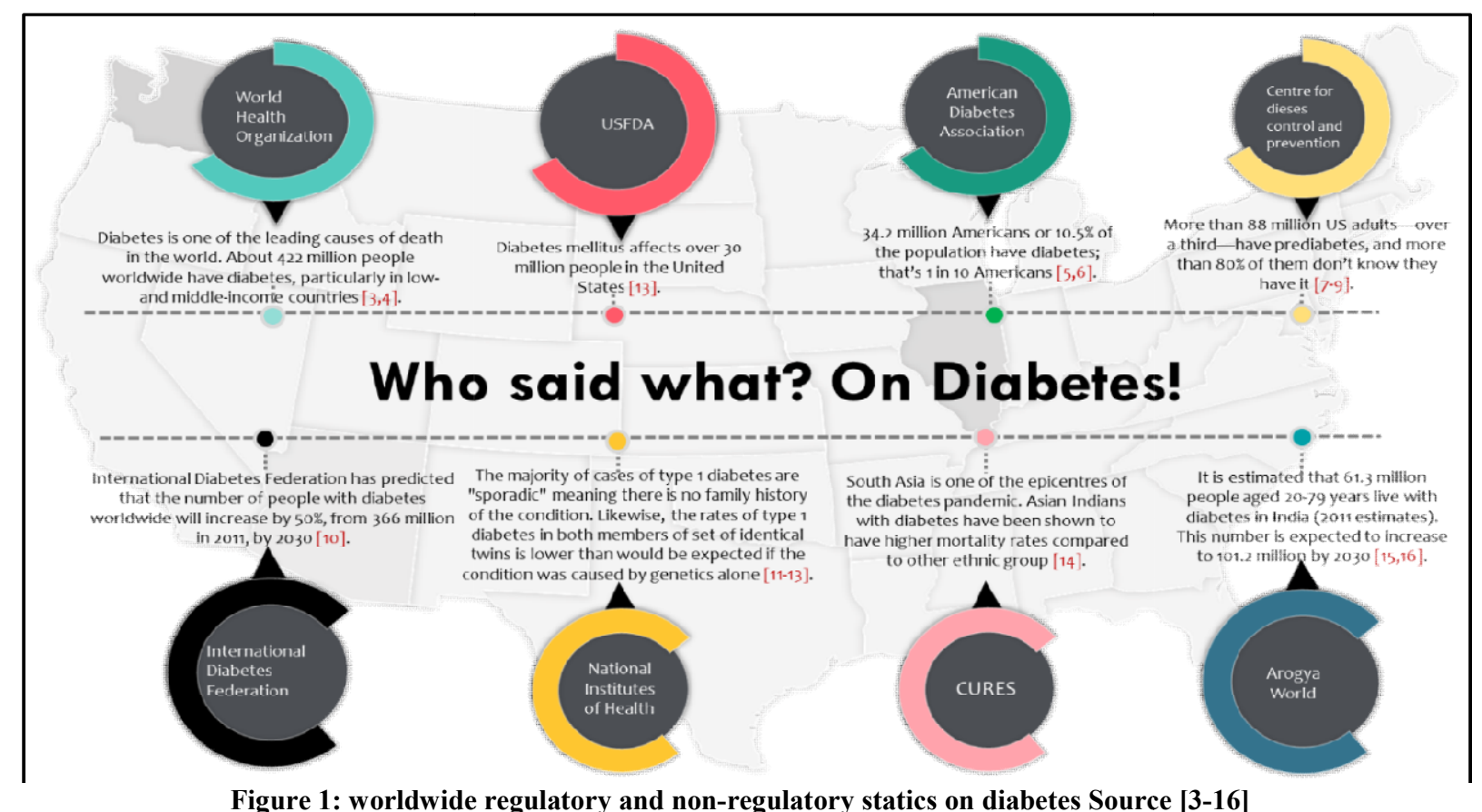

Figure 1: worldwide regulatory and non-regulatory statics on diabetes Source [3-16]

Arogay world predicted that diabetes cases figure is predicted to increase to 101.2 million by $2030[15, \mathbf{1 6}]$. The rest of the regulatory and non-regulatory institutions discussion on diabetes if listed in figure-1 above. Irregular carbohydrate metabolism leads to higher blood glucose level than normal, that may be a root of numerous complications like nephrotoxicity and retinopathy and finally death of a diabetic person [17]. In the case of Chronic illness due to diabetes instabilities of metabolism of proteins, lipids [18] occur that 
and promotes peroxidation of lipids of membrane resulting in trouble in cell function. Hyperglycemia also promotes nonenzymatic glycation of proteins promoting an increase in the development of reactive oxygen species [19].

There is a long history of herbal use as antidiabetic therapy. In the future also there is need for herbal antidiabetic therapy and the validated antidiabetic potential of many plant remedies that are available in the literature showing controlled analyses in healthy and diseased animals as well as humans in the last ten years. The mode of the antidiabetic effect of herbal remedies involves the modulation of carbohydrate metabolism by restoring the integrity and function of the $\beta$ cells $[\mathbf{2 0}, \mathbf{2 1}]$. In this regard Citrullus colocynthis Schrad is a proven anti-diabetic plant for many years, it belongs to the Cucurbitaceae family and is an annual plant that grows in native to North Africa, the Middle East and South Asia Southern Europe, [22]. It is a perennial herb usually dragging. It is commonly found wild in the sandy lands; it's extremely bitter tastes and violent purgative properties are well known [23]. Hence, its popular common names in English are bitter apple, bitter cucumber, colocynth, and bitter gourd [24]. The appearance of CCS (Figure 2 A) resembles that of watermelon, possessing herbaceous stems, triangular and hairy leaves, yellow flowers, and globular bitter fruit. Its fruit consists of an outer hard rind and an inner white spongy pulp. A large number of seeds are embedded in its pulp [25]. Further fruit is yellow and smooth [26].

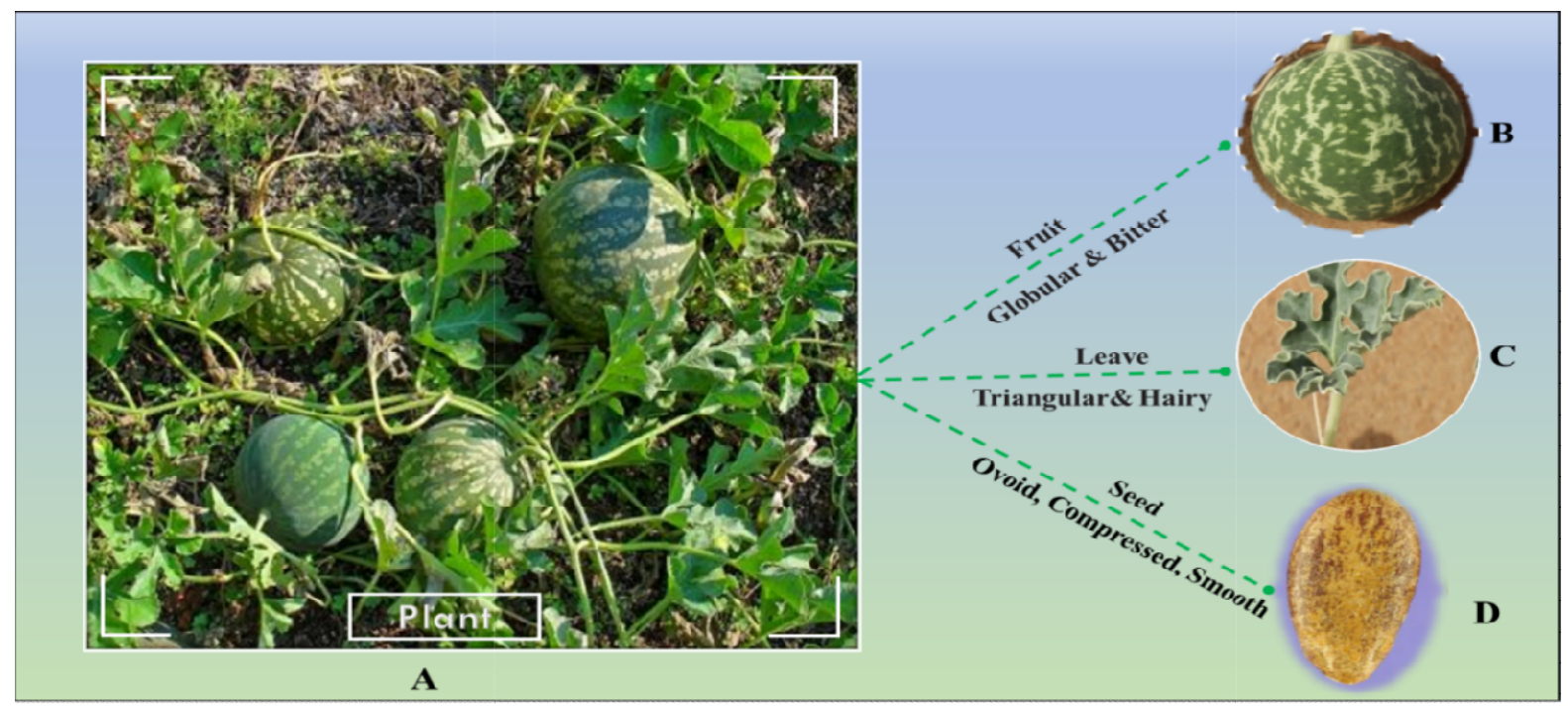

Figure 2 A: Citrullus colocynthisSchradwhole plant, $B=$ Fruit, $C=$ Leave, and $D=$ Seed

The main medicinal fragment of the plant is the fruit pulp, and other medicinal parts of the plant are the seed, leaf, and root $[\mathbf{2 8}, \mathbf{2 9}]$. The objective of this review is to collect and summarize under one roof of all such data, which involve the study of the antidiabetic 
effect of parts of $C C S$. The detailed-on fruit and other medicinal parts along with their past proven activities are discussed in the below section:

\subsection{Fruits of CCS:}

As discussed above, the fruit of this plant (Figure 2 B) is globular, yellow, and smooth, which when ripe contains within it a hardcoriaceous rind, and a white spongy pulp enclosing many ovate compressed white or brownish seeds $[\mathbf{2 6}, \mathbf{3 0}]$. It is hard having skin around it and contains 200-300 seeds/gourd [31]. The fruit is also slightly depressed, 5$7.5 \mathrm{~cm}$ in diameter, and gets white glabrous when ripe. The fruit is loaded up with a dry, elastic exceptionally harsh mash. Each unpleasant apple plant delivers around 15-30 globular fruits having a diameter of almost 7$10 \mathrm{~cm}$. The external segment of the organic product is secured with green skin having yellow stripes [32]. A few bioactive chemical constituents of fruits are recorded, such as glycosides, alkaloids, fatty acids, flavonoids, and essential oils. The isolation and identification of a valuable constituent of fruit Cucurbitacins A, B, C, D, E, I, J, K, and L and colocynthosides $\mathrm{A}$ and $\mathrm{B}$ are also reported [33]. Traditionally and Ethnomedicinally CCS fruit is used for numerous treatments like:

Diabetes: Pulp of ripe CCS fruits is trampled by naked feet till feeling of bitter taste appears in the mouth for 15 days and root powder is also used in diabetic patients in some areas of Haryana and Rajasthan.

$>$ Constipation: Decoction of fresh fruits of " $C C S$ " is prepared in water in ratio of 1 : 6. Five $\mathrm{ml}$ decoction is administered orally at bed time for three days.

Deafness: Ripe whole fruits or pericarp of "CCS" is boiled in Sarson/Mustard Oil (Brassica campestris L., FamilyBrassicaceae) in a ratio of 1: 7 . Three to four drops of this oil are dropped in the affected ear two times in a day till ailment is cured completely.

Flatulence: Ripe "CCS" fruits are stuffed with black pepper (Piper nigrum L., Family-Piperaceae) through a hole made in the pericarp. Each fruit is shielded with mud and baked in the cow-dung fire till it becomes red. The ash of "CCS" fruit and black-pepper are collected and stored. Half gm ash is given after each meal for 15 days.

To promote lactation: Decoction of fresh fruit of "CCS" is prepared in water in ratio of 1: 6. Two $\mathrm{ml}$ decoction is administered orally twice daily for seven days.

Pimples: The fruit and roots with or without Nux-vomica, is rubbed into a paste with water. The paste is applied externally on pimples, till a complete cure is achieved.

Stomach ache: Small fruits of ' $C C S$ ' are collected and stuffed with salt and 
'Ajwain'. The fruits are dried and ground to make powder. Two g powder is given orally twice in a day for 2 days.

$>$ Jaundice: Fresh fruit pulp of ' $C C S$ ' is mixed with 'Ajwain' seeds and this mixture is kept for seven days and then dried in shade, grind to powder. $2 \mathrm{~g}$ powder is given orally twice in a day for 3 days.

Piles: Dry fruit pulp is kept in water overnight in the earthen pots. Regular washing of anal part after nature's call in the morning [34].

Bande and Co-workers determined basic dimensions and mass of $C C S$ fruit with a digital gauge that aimed to give information on the loading capacity in transportation and storage of the harvested fruit before processing; they reported scale with accuracy $0.01 \mathrm{~mm}$ and $0.01 \mathrm{~g}$, respectively. Maximum length, width, thickness, and mass of 100 samples were $12.86 \mathrm{~cm}, 12.53 \mathrm{~cm}, 15.52 \mathrm{~cm}$, and $1031.5 \mathrm{~g}$, respectively. Arithmetic and geometric mean diameters were between 5.68 and 13.63 and 5.58 and $13.22 \mathrm{~cm}$ while mean bulk and true densities were 404.98 and $1074.6 \mathrm{~kg} / \mathrm{m} 3$ on 3 and 6 runs, respectively. The sphericity and aspect ratio were about 1 , with an average packaging coefficient, on five separate runs, of 33.49. The average vertical and horizontal weight to break the fruit was 121.23 and $74.09 \mathrm{~kg}$, respectively [35]. Generally, the average mass of CCS fruit is $506 \mathrm{~g}$, and the mass of pulp is almost
$50 \%$ of the mass of fruit, while the seed content is $71.8 \mathrm{~g}$ [36]. Marzouk et al., 2011 examined the anti-inflammatory activity of aqueous extracts of CCS fruit at a juvenile phase utilizing the carrageenan-induced paw edema assay in rats. The best antiinflammatory activities were gotten with immature fruits from south Tunisia. Consequently, CCS could be a valuable item appropriate for additional assessment of inflammatory diseases [37]. Bactericidal exercises of unrefined concentrates, divisions and mixes of $C C S$ plant flying parts and ready deseeded natural products were performed against the medication touchy standard strain of Mycobacterium tuberculosis $\mathrm{H} 37 \mathrm{Rv}$ (ATCC 27294), 16 medication safe strains of Mycobacterium tuberculosis and two Mycobacterium other than tuberculosis (MOTT) strains, utilizing radiometric BACTEC framework. Methanolic concentrate of a ready deseeded product of CCS indicated great movement $(\mathrm{MIC}=62.5 \mu \mathrm{g} / \mathrm{ml})$ and one of the bioactive parts exhibited the best action (MIC $31.2 \mu \mathrm{g} / \mathrm{ml}$ ) against Mycobacterium tuberculosis H37Rv [38].

\subsection{Leaves of $C C S$ :}

The leaves (Figure. 2 C) stand alternately on long petioles. They are triangular, many cleft, variously sinuated, obtuse, hairy, a fine green on the upper surface, also rough and pale underneath [30] they are 2-4 inches long, with 3-7 profound lobes; and solitary light-yellow blossoms are found [39]. Sometimes leaves 
are very variable in size. The wild leaf is $3.8^{-}$ $6.3 \mathrm{~cm}$ in length and $2.5 \mathrm{~cm}$ in width while cultivated leaves are large. The leaf shows deltoid margin, the pale green color above and ashy colon beneath, scabrid on both surfaces, 5-7 lobed. The angular leaves are alternately situated on long petioles. Each leaf is about 5-10 $\mathrm{cm}$ long and has around 3-7 lobes. Some of the time the center flap may have an applaud structure. The leaves have an unpleasant, shaggy surface with open sinuses [32]. Cucurbitacin is a major chemical constituent of leaves of CCS [40] apart from this Quercetin [41] alkaloids, flavonoids, and glycosides are possible constituents responsible for various activities [42]. Traditionally and Ethnomedicinally leaves of $C C S$ is used for numerous treatments like:

> Leukoderma: Fresh leaf extract, obtained by squeezing pounded leaves in a muslin cloth, is put on affected areas of skin twice or thrice a day. Seed oil is kept to depigmented areas every third day. The therapy is continued until the pigments reappear and become stable. This is a reputed therapy for leukoderma in the study area.

Skin lice infection: Leaf juice, boiled with pure mustard oil, filtered and massaged all over the body before bath.

In a study conducted by Sagar et al., 2018 various extracts viz alcoholic, acetone, chloroform of the leaves of CCS were assessed for antibacterial activity against
Staphylococcus aureus and E.coli and it was observed that none of the extracts displayed antibacterial activity against both the bacteria when compared to standard antibiotic [43]. Cucurbitacin glucosides extracted from CCS leaves have shown growth-inhibitory activity on human breast cancer cells [44].

\subsection{Seeds of $C C S$ :}

The seeds are small (6mm in length), ovoid (Figure 2 D), compressed, smooth, and brownish when ripe. Seeds constitute about $75 \%$ of the weight of the fruit of CCS [31] While growing on marginal lands, about $6,500 \mathrm{~kg}$ ha-1 seed yield is possible with little effort since this plant seed has high oil contents of up to $53 \%$ [45]. The seeds contain flavonoids and polyphenolics [46], Fatty acids like palmitic acid, stearic acid, linoleic acid, oleic acid $[47,48]$ and tocopherols and carotenes like a-tocopherol, $\beta$--tocopherol, $\beta$ caroteneFruitseedoil [49]. Traditionally and Ethnomedicinally seeds of $C C S$ is used for numerous treatments like:

$>$ Premature greying of hairs: Mature "CCS" seeds are compressed to extract the oil. Regular application of this oil is claimed to impart natural black color to the grey hair.

Malaria: Pulp of seeds eaten twice a day for 2 days.

Scarcity: Seeds of ' $C C S$ ' are beneficial in scarcity. Bitter seeds buried in common salt to wash-off their bitter principles, 
dried and mixed with Bajra seeds and the mixed flour is taken [34].

The seeds of $C C S$ are known to possess: $567.32 \mathrm{kcal} / 100 \mathrm{~g}$ dry weight, $17 \%-23 \%$ fatty acids, of which a low amount of free fatty acids $(1.57 \%$ total seed weight and $7 \%$ total oil) and both triglycerides and free fatty acids comprise mostly linoleic acid (66\%-76.4\%), palmitic acid $(6.3 \%-8.1 \%)$, oleic acid $(7.8 \%-$ $14.2 \%)$, and stearic acid (6.1\%-7.3\%); proteins at $11.7 \%$ of total weight; nonfibrous carbohydrates at $29.5 \%$ total weight; dietary fiber at $5.51 \%$ total weight; $7.51 \pm 0.53 \%$ moisture content; $2.9 \%-3.2 \%$ ash content (dry weight); vitamin $\mathrm{E}$ at $121.85 \mathrm{mg} / 100 \mathrm{~g}$ with a high ?-tocopherol content (116.36 \pm $0.15 \mathrm{mg} / 100 \mathrm{~g} ; 95 \%$ total vitamin E) and lower a $(0.72 \pm 0.06 \mathrm{mg} / 100 \mathrm{~g}), ß(0.57 \pm$ $0.03 \mathrm{mg} / 100 \mathrm{~g})$, and d $(4.19 \pm 0.12 \mathrm{mg} / 100 \mathrm{~g})$ content [48]. Mariod et al. (2009) investigated the fruit characteristics of $C C S$; they reported $14.8 \mathrm{~g}$ dry fruit weight, $13.0 \mathrm{~cm}$ fruit length, and $13.0 \mathrm{~cm}$ fruit diameter. They found that the weight of dried seeds was 4.6 $\mathrm{g}$, while the weight of dried pulp was $10.2 \mathrm{~g}$. These authors reported that the dried pulp of CCS represented more than $68.9 \%$ of dry fruit weight. The CCS seeds showed 15.75\% protein content, carbohydrates as 17.01 and ash as $4.62 \mathrm{~g} / 100 \mathrm{~g}$, respectively. The oil content of CCS is $27.10 \%$ of the seed weight. The oil obtained from the seed of CCS showed good physicochemical properties like the refractive index $\left(40+1^{\circ} \mathrm{C}\right)$ is 1.429 , the relative density $\left(30 \pm 1^{\circ} \mathrm{C}\right)$ is 0.886 , the unsaponifiable matter is $0.8 \%$, and iodine value is 112.7. Arbi Nehdi et al and coworkers' research work gave new data to the world where, they evaluated the physicochemical properties, fatty acid, tocopherol, thermal properties, 1H NMR, FTIR and profiles of non-conventional oil extracted from CCS. Seeds were evaluated and compared with conventional sunflower seed oil. Besides, the antioxidant properties of CCS seed oil were also evaluated. The oil content of the CCS seeds was $23.16 \%$. The main fatty acids in the oil were linoleic acid (66.73\%) followed by oleic acid (14.78\%), palmitic acid (9.74\%), and stearic acid (7.37\%). The tocopherol content was 121.85 $\mathrm{mg} / 100 \mathrm{~g}$ with c-tocopherol as the major one (95.49\%). The thermogravimetric analysis showed that the oil was thermally stable up to 286.57 ${ }^{0} \mathrm{C}$, and then began to decompose in four stages namely at $377.4{ }^{0} \mathrm{C}, 408.4{ }^{0} \mathrm{C}$, $434.9{ }^{\circ} \mathrm{C}$, and $559.2{ }^{0} \mathrm{C}$. The present study showed that this non-conventional $C C S$ seed oil may be utilized for food and non-food applications to supplement or replace a few of the conventional oils. CCS seeds showed significant antihyperlipidemic results on New Zealand rabbits. The hypercholesterolemic control rabbits remained hypercholesterolemic throughout the experimental time but serum cholesterol and triglyceride in the groups administered with both seeds and pulps extracts of CCS were 
reduced $(\mathrm{p}<0.05)$. The reduction of LDL-C in the groups treated with the pulp extracts and $100 \mathrm{mg} / \mathrm{kg}$ seed extract was significant $(p<0.05)$. The impact of CCS on the blood lipid profile in rabbits might be because of high measures of saponins in CCS which diminished cholesterol levels by lessening the ingestion of cholesterol, expanding the repulse of feces estriol and looseness of the bowels because of expanded peristalsis.

\section{DIVERSE PARTS OF CITRULLUS} COLOCYNTHIS SCHRAD AND THEIR
CHEMICAL CONSTITUENTS

A few bioactive compounds of CCS plant have been verified in the literature. They are assembled as carbohydrates, flavonoids, alkaloids, glycosides, fatty acids, and essential oils; however, there are just a couple of reports on the isolation and identification of individual chemical constituents [42]. Table 1 represents the summary of various chemical constituents of different parts of CCS.

Cucurbitacins have been reported as the main components of CCS fruits. Numerous investigations announced the presence of alkaloids in the CCS fruit, however, just a couple of reports are accessible on the isolation and identification of individual alkaloids [42]. Gurudeeban et al., identified 17 volatile compounds from the fruit pulp, ranging from $0.51 \%$ to $48.0 \%$ of peak area the alcohols identified were 4-(1methyl)ethoxy-1-butanol; 5-methoxy, 2- methyl 1,2-pentanol;1-cyclopentyl,2-propene1-ol and 2-furanm ethanol, tetrahydro 5methyl-cis and trans-isomers. The ketones characterized were 3,4-dimethyl ,2-hexanone; 2 methyl,4heptanoneand 3-methyl,2heptanone. Two epoxy compounds (1 propoxy pentane and 2,3-epoxy methyl propionate) were identified. The seed kernels contain about $50 \%$ oil, $30 \%$ protein, $10 \%$ carbohydrate, $4 \%$ ash, and $3 \%$ fiber. $C C S$ is also an excellent source of different amino acids asarginine, methionine, and tryptophan. In another report, the key mineral component from CCS was found to be phosphorus, potassium, magnesium, manganese, sulfur, calcium, iron, and zinc.

\section{ANTI-DiABETIC POTENTIAL OF} CITRULLUS COLOCYNTHIS SCHRAD:

Diabetes is one of the fastest-growing metabolic diseases. The treatment is symptomatic and requires life-long use of chemical drugs, which produce numerous adverse actions in addition to high cost, hence, the search for more effective and safer anti-diabetic continues. CCS has been broadly utilized as anti-diabetic in various nations and interestingly attracted an enormous number of studies both on animals and humans. Few invivo studies are discussed below and listed in Table 2. Recently, the impact of the aqueous extracts from the seeds on the biochemical parameters of normal and streptozotocin (STZ) induced diabetic rats was determined by a researcher. Diabetes was instigated by a 
single intraperitoneal (60 $\mathrm{mg} / \mathrm{kg}$ body $\mathrm{wt})$ injection of STZ. Oral administration of the plant extract $(300 \mathrm{mg} / \mathrm{kg}$, daily for 2 weeks) diminished the plasma level of AST and LDH significantly, while it failed to reduce the raised blood level of GGT and ALP in diabetic rats.

$C C S$ has been traditionally utilized as a medicinal plant for diabetes; since it induces insulin secretion from the pancreas after supplementation, while reducing blood glucose and improving lipid levels. Oral ingestion of the fruit at doses lower than (300-800 mg daily) tends to be prescribed in some Middle Eastern locations for the treatment of diabetes to avoid the intestinal side effects. There is one such study in the literature, which involved the use of leaf extract of CCS. Where researchers investigated the hypoglycemic influence of $C C S$ on hepatic hexokinase and gluconeogenic enzymes like glucose-6phosphatase and fructose 1,6-bisphosphatase of control and AID rats after oral intake of its leaf suspension in the doses of $250 \mathrm{mg} / \mathrm{kg}$ and $500 \mathrm{mg} / \mathrm{kg}$ of body weight for sixty days and found a significant fall in blood glucose level from $381+34$ to $105+35 \mathrm{mg} / \mathrm{dL}$. There was a reduction in the activities of glucose- 6 phosphatase and fructose 1,6- bisphosphatase, and an enhancement in liver hexokinase activity supporting the hypoglycemic importance of this medicinal plant. TanninSpitz et al, studies the differential impacts of diets supplemented with $C C S$, sunflower, or olive oils on the pancreatic M-cell mass in streptozotocin $(S T Z)$-induced diabetes in rats. $S T Z$ injection-induced rapid hyperglycemia in all animals. However, after 2 months, hyperglycemia was significantly less pronounced in the rats fed a CCS oil-enriched diet compared with other rat groups. Evaluation of insulin sensitivity using the homeostasis model assessment technique also showed less insulin resistance in the rats fed on a $C C S$ oil-enriched diet than the other rats. Two months after STZ injection, the pancreatic M-cell mass was similar in both $S T Z$-treated rats fed the colocynth oilenriched diet and their controls fed the same diet.

Antidiabetic action of petroleum ether fruits extract of CCS against Streptozotocin initiated hyperglycemic rats was assessed after oral administration of two distinct doses (300 and $500 \mathrm{mg} / \mathrm{kg}$ ) of CCS. Phytochemical investigations revealed the following chemical constituents like alkaloids, terpenes, saponins, and glycosides. Administration of petroleum ether extract of CCS fundamentally enhanced the bodyweight of diabetic rats in a dose and time-dependent manner. CCS showed antidiabetic action through stimulation of $\beta$-cells of islets of Langerhans by releasing more insulin and this effect was brought about by constituents like glycosides, saponins, flavonoids [48]. Salami et al. also observed significant hypoglycemic effects of 
suspensions of CCS fruit pulp in normal $12 \mathrm{~h}$ fasting rats after a single dose of $30 \mathrm{mg} / \mathrm{kg}$, while suspensions of CCS fruit pulp in the doses of $10 \mathrm{mg} / \mathrm{kg}$ and $90 \mathrm{mg} / \mathrm{kg}$ exhibited non-significant hypoglycemic effects. The effect of hydro-ethanolic extract of CCS pulp was studied on alloxan-induced hyperlipidemia in diabetic rats and the results predicted noticeable decrease in the of total cholesterol levels, free fatty acids, triglycerides, and phospholipids in serum and liver of diabetic rats treated with CCS when compared to diabetic untreated rats. Agarwal et al., 2012 examined the effect of the root of $C C S$ on the biochemical parameters of normal and alloxan-induced diabetic rats. Diabetes mellitus was induced by intraperitoneal (120 $\mathrm{mg} / \mathrm{kg} \quad$ b.wt.) injection of alloxan monohydrate for three days and the animals presenting blood glucose level in the range of 175-300 mg/dL were included for study. The blood glucose concentrations of the animals were estimated at the start of the examination and the estimations were rehashed on the third, fifth, and seventh day after the beginning of the analysis. Aqueous extract of roots of CCS indicated a noticeable change in blood sugar level (58.70\%) when compared with chloroform (34.72\%) and ethanol extracts $(36.60 \%)$. The aqueous extracts demonstrated improvement in parameters like body weight, serum urea, serum creatinine, and serum protein as well as lipid profile and also restored the serum level of bilirubin total, conjugated bilirubin, serum glutamate oxaloacetate transaminase (SGOT), serum glutamate pyruvate transaminase (SGPT) and alkaline phosphatase (ALP) [46]. The effect of CCS pulp extract on the structure of the liver was tested in diabetic rats at both light and scanning electron microscopic levels. Diabetes produces degenerative changes in the form of disorganization of the hepatic cords, cytoplasmic vacuolization, and pyknosis of the nuclei of hepatocytes and inflammatory cell infiltration. The SEM examination of these livers exposed various lipid droplets within hepatocytes, damaged blood sinusoids, and haemorrhage of erythrocytes between hepatocytes and inside Disse's spaces. The liver of $C C S$-treated rats revealed slight histological alterations versus the control animals. All these reports supported the potential of $C C S$ as a traditional medicine in diabetes and suggested it to be a safe modern antidiabetic agent.

\section{CLINICAL TRIALS CONDUCTED ON CITRULLUS COLOCYNTHIS SCHRAD PLANT:}

Human trials always provided an evidence for the efficacy and safety of a drug when conducted ethically for the advantage of society, some clinical studies performed worldwide on Citrullus colocynthis Schrad plant are summarized below:

\subsection{Study title:}


Evaluation of topical citrullus colocynthis schrad fruit oil efficacy in treatment of painful peripheral diabetic neuropathy.

\section{Study details:}

Study / Registration number: NCT02155361,

Sponsor: Shiraz University of Medical

Sciences.

\section{Brief summary:}

This research was intended to assess the topical CCS fruit oil efficacy in the treatment of painful peripheral diabetic neuropathy $(\mathrm{PDN})$ in a randomized double-blind placebocontrolled clinical trial design. This study included 60 patients with painful conditions other than PDN like radiculopathies were excluded. After giving the Informed consent the patients were undergone NCS (Nerve Conduction Study) before recruitment. Study arms od this study were topical CCS fruit oil (1\%) for Phase 1 and Topical vehicle oil for Phase 2. Study primary outcome measure was Pain Scores on the Neuropathic Pain Scale (NPS) [Time Frame: 12 weeks]. Participants were from 18 Years to 70 Years (Adult, Older Adult) of both the Sexes. Inclusion criteria for this trial were Patients having Controlled type 1 or 2 diabetes mellitus. Painful Peripheral diabetic neuropathy for more than 3 months and Patients consent on enrolling study and admitting study protocol. This trial was conducted in Iran under the investigation and Study Chair of Mesbah Shams, M.D. Research Center for Traditional Medicine \&
History of Medicine. The study is completed but no official results are posted yet.

\section{2: Study title:}

The clinical investigation of Citrullus colocynthis Schrad fruit in treatment of type II diabetic patients: a randomized, double blind, placebo-controlled clinical trial.

\section{Study details:}

Study / Registration number: 207-Q1/8/1383., Sponsor: Endocrinology and Metabolism Research Centre, Tehran University of Medical Sciences, Tehran, Iran.

\section{Brief summary:}

A total of 50 of type II diabetic patients (aged 40-65 years), registered at the Diabetic Clinic registry of Shariati Hospital, were selected and enrolled in this study. Written informed consent was obtained from each patient. All the patients who participated (12 males and 38 females) had a confirmed diabetes type II diagnosis with Inclusion criteria type II diabetes with a fasting blood glucose of less than $200 \mathrm{mg} / \mathrm{dL}$ and with a disease duration of 2-8 years, body weight between 55 and 75 $\mathrm{kg}$, normal blood pressure and lipid levels. The selected $300 \mathrm{mg}(5 \mathrm{mg} / \mathrm{kg}$ for an average of $60 \mathrm{~kg}$ body weight/day) dried fruit powder in 3 separate doses was the lowest of doses of $C C S$ prescribed by 10 herbalists (range of doses 300-800 $\mathrm{mg} /$ day) with no gastrointestinal disturbance. Fasting glucose levels were accessed by the glucose-oxidase technique using a Beckman Glucose-2 
Analyzer immediately after blood sampling. All the patients completed 2 months of therapy. The demographic and paraclinical characteristics of two groups at the start of the trial were significant. The results predicted that $C C S$ fruit treatment has a beneficial effect on lowering the glycemic state in type II diabetic patients. The use of this herbal medicine at a dose of $300 \mathrm{mg} /$ day in 3 divided doses showed no adverse gastrointestinal symptoms or liver and kidney abnormalities during 2 months of therapy.

\section{3: Study title:}

The effect of Citrullus colocynthis Schrad fruit extract on blood sugar in type II diabetic patients: a double-blind clinical trial.

\section{Study details:}

Study / Registration number: RCT2013010211984N1. Sponsor: Vice chancellor for research, Zahedan University of Medical Sciences, Karaj, Iran.

\section{Brief summary:}

In the present clinical study, 80 patients were enrolled with type II diabetic patients aged between 30 to 60 years, with fasting blood glucose between 150-220 mg/dl and HbAlc $7.5-10 \%$ taking two metformin $500 \mathrm{mg}$ or two glibenclamide $5 \mathrm{mg}$ tablets daily, with a minimum two-year history of diabetes that not changed the antidiabetic regimen before 3 months. This was an inclusion criterion; patients were of both the genders for Phase 23. The patients signed the written informed consent and randomly allocated into $C C S$ and placebo groups. The patients were allowed to continue their standard anti-diabetic therapy without any change during the study. The patients in the CCS group were treated by $C C S$ capsules of $100 \mathrm{mg}$ three times in a day and other groups with a placebo capsule in the same manner for 4 months. At close of the trial the fasting blood glucose, glycosylated hemoglobin, cholesterol, LDL, HDL, triglyceride, aspartate aminotransferase, alanine aminotransferase, and creatinine levels were measured in both groups. Mr. Hasan Fallah Huseini is investigating the trails in Iran, no results are published yet.

\section{4: Study title:}

The efficacy of Citrullus colocynthisSchrad fruit on fasting blood glucose and glycosylated haemoglobin as well as its possible side effects among the patients with type II diabetes.

\section{Study details:}

Study / Registration number:EC/92/H/187. Sponsor: Faculty of Medicine, Ilam university of Medical Sciences, Ilam, Iran.

\section{Brief summary:}

In another clinical investigation in Iran, 70 patients having diabetes were investigated by dividing them into two groups of intervention and placebo randomly and were studied for 2 months. The mean serum level of FBS and HbA1c was compared within and between groups at the end of the trial. Data were analyzed using student and paired t-tests via 
SPSS software version 16. The trial outcomes were noticed as an important variation was between before and after intervention for HbA1c and FBS levels in the intervention group ( $\mathrm{P}=0.01$ and $\mathrm{P}=0.04$, respectively). The difference between before and after intervention for FBS and HbAlc levels in the placebo group was not significant $(\mathrm{P}=0.8, \mathrm{P}$ $=0.68$ respectively). This trail displayed a negative relationship between either the mean \pm standard deviation serum level of FBS or $\mathrm{HbA1c}$ and body mass index in the treatment group significantly $(\mathrm{P}=0.03,0.008$, respectively). This study did not identify any side effects during the trial period among the treatment group. As per the discoveries of this research, the application of $125 \mathrm{mg} C C S$ once in a day for two months may lead to a significant reduction in the mean levels of HbA1c and FBS among the patients with type II diabetes without any adverse event.

\section{5: Study title: "Effectiveness of bitter} apple oil (citrulluscolocynthis) versus coconut oil foot massage on neuropathic pain, among patients with diabetes mellitus at selected rural area, Puducherry".

\section{Brief summary:}

A clinical study was done with the primary objective to evaluate the existing level of Neuropathic pain among patients with diabetes mellitus in Group-I and Group- II. And to assess the viability of bitter apple oil (Group-I) and coconut oil (Group-II) foot massage on neuropathic pain among patients with diabetes mellitus. Where a Randomized controlled trial design was implemented. 90 samples were assigned utilizing a Simple random sampling method. Group I received bitter apple oil foot massage and Group II received coconut oil foot massage for a month. Data were examined by clear and inferential insights, results indicated that. The examination discoveries revealed that bitter apple oil foot massage was effective to reduce neuropathic pain $(p<0.001)$ than coconut oil foot massage. This trial concluded that diabetic neuropathy pain is the important need of patients with Diabetes Mellitus which should be intervened by a nurse. The bitter apple oil foot massage is a boon to alleviate the pain of the suffering diabetic population. This investigation demonstrates that bitter apple oil foot massage was effective than coconut oil on reducing neuropathic pain.

\section{PATENTS FILED ON CITRULLUS}

\section{COLOCYNTHIS SCHRAD PLANT:}

Filing and approval of a patent is a final confirmation about a commercial interest of a particular article. In this regard, various patents have been granted to the researcher for their innovation and research work on Citrullus colocynthis Schrad. The patents offer an owner the exclusive rights to an invention and prevent others to misuse it. A few of the patents which are granted to the researcher for their novel work on $C C S$ are discussed below in Table 3. 
Table 1: Medicinal part and chemical constituents of different parts of Citrullus colocynthis Schrad

\begin{tabular}{|c|c|c|c|}
\hline $\begin{array}{l}\text { Sr. } \\
\text { No }\end{array}$ & $\begin{array}{l}\text { Medicinal } \\
\text { Part }\end{array}$ & Chemical constituents & $\begin{array}{l}\text { Phytoconstituents responsible } \\
\text { for activity }\end{array}$ \\
\hline \multirow[t]{2}{*}{1} & \multirow[t]{2}{*}{ Fruits } & In methanolic extract & In methanolic extract \\
\hline & & $\begin{array}{l}\text { Ursolic Acid andCucurbitacin E 2-O- } \beta \text {-D- } \\
\text { glucopyranoside. }\end{array}$ & Phenoliccompounds. \\
\hline \multirow[t]{2}{*}{2} & \multirow[t]{2}{*}{ Fruits } & In Butanol fraction hydro-methanolic extract & In Hydroalcoholic extract \\
\hline & & 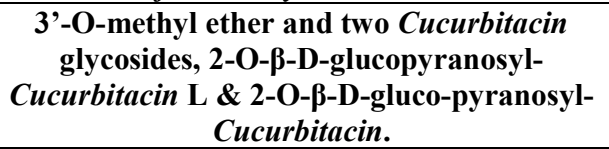 & $\begin{array}{l}\text { Glycosides and resins, } \\
\text { colocynthin andcolocynthin } \\
\text { alkaloids. }\end{array}$ \\
\hline \multirow[t]{2}{*}{3} & \multirow[t]{2}{*}{ Fruits } & In Ether extract & In Petroleum ether \\
\hline & & $\begin{array}{c}\text { elatericin B (II)(Cucurbitacin I) } \\
\text { dihydroelatericin B (III) and } \\
\text { tetrahydroelatericin B (IV), elaterinidell. }\end{array}$ & $\begin{array}{l}\text { Saponins, flavonoids, and } \\
\text { glycosides. }\end{array}$ \\
\hline \multirow[t]{2}{*}{4} & \multirow[t]{2}{*}{ Fruits } & In Chloroform: Methanol (1:1) ratio & In Aqueous extract \\
\hline & & $\begin{array}{c}\text { Cucurbitacin E and Cucurbitacin I } \\
\text { glycosides. }\end{array}$ & $\begin{array}{l}\text { Alkaloids,iridoids, flavonoids, } \\
\text { steroids. }\end{array}$ \\
\hline \multirow[t]{2}{*}{5} & \multirow[t]{2}{*}{ Fruits } & In Butanol extract & In Ethanolic extract \\
\hline & & 2-O-D-glucopyranosyl-Cucurbitacin E & $\begin{array}{l}\text { Alkaloids,flavonoids, } \\
\text { \&glycosides. }\end{array}$ \\
\hline \multirow[t]{2}{*}{6} & \multirow[t]{2}{*}{ Fruits } & In Fruit extract & In Aqueous extract \\
\hline & & $\begin{array}{c}\text { 2-O- } \beta \text {-D- glucopyranosyl Cucurbitacins I, J, } \\
\text { K, and L. }\end{array}$ & Saponin, glycosides. \\
\hline \multirow[t]{2}{*}{7} & \multirow[t]{2}{*}{ Whole Plant } & In Methanolic extract & In Ethanolic \& aqueous extracts \\
\hline & & $\begin{array}{c}\text { colocynthins } \mathrm{A}, \mathrm{B} \& \mathrm{C} \text { along with } \beta- \\
\text { sitosterol, 3-O- } \beta \text {-D-glucopyranoside, } \\
\text { elaterinide, and bryoamaride. }\end{array}$ & $\begin{array}{l}\text { Flavanoids, saponins, alkaloids, } \\
\text { and tannins. }\end{array}$ \\
\hline \multirow[t]{2}{*}{8} & \multirow[t]{2}{*}{ Whole Plant } & In Chloroform extract & In Butanolic extract \\
\hline & & 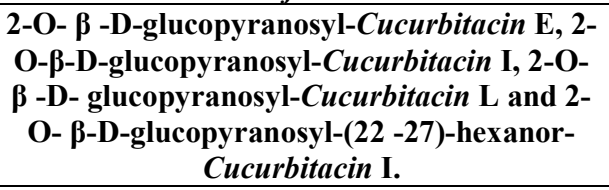 & Cucurbitacin E Glycoside. \\
\hline \multirow[t]{2}{*}{9} & \multirow[t]{2}{*}{ Leaf } & In Ethyl acetate extract & $\begin{array}{c}\text { In Aqueous \& Methanolic } \\
\text { extracts }\end{array}$ \\
\hline & & 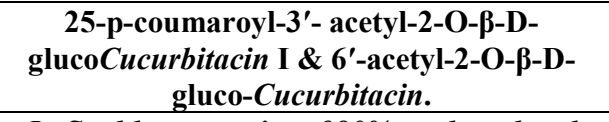 & Alkaloids, Tannins, Flavonoids. \\
\hline \multirow[t]{2}{*}{10} & \multirow[t]{2}{*}{$\begin{array}{l}\text { Leaf, Stem, } \\
\text { Fruit, and } \\
\text { Root }\end{array}$} & $\begin{array}{c}\text { In Soxhlet extractionof } 80 \% \text { methanol and } \\
\text { then re-extracted with petroleum ether, } \\
\text { diethyl ether, and ethyl acetate }\end{array}$ & In Aqueous and diluted acetone \\
\hline & & Quercetin. & $\begin{array}{l}\text { Tannins, steroids, pigments and } \\
\text { flavonoids, alkaloids, iridoids. }\end{array}$ \\
\hline
\end{tabular}


Table 2: In-vivo anti-diabetic potential of Citrullus colocynthis Schrad

\begin{tabular}{|c|c|c|c|c|}
\hline $\begin{array}{l}\text { Plant } \\
\text { Part }\end{array}$ & Extract & Dose & $\begin{array}{c}\text { In-Vivo } \\
\text { Tested } \\
\text { Sample }\end{array}$ & Outcomes and Reference \\
\hline Seeds & $\begin{array}{l}\text { Aqueous } \\
\text { Extracts. }\end{array}$ & $\begin{array}{l}300 \mathrm{mg} / \mathrm{kg} \text {, daily for } \\
2 \text { weeks. }\end{array}$ & Rats. & $\begin{array}{c}\text { Reduced the plasma level of AST and LDH } \\
\text { significantly[37]. }\end{array}$ \\
\hline Leaf & $\begin{array}{c}\text { Leaf } \\
\text { Extract. }\end{array}$ & $\begin{array}{l}250 \mathrm{mg} / \mathrm{kg} \text { and } \\
500 \mathrm{mg} / \mathrm{kg} \text { of body } \\
\text { weight for sixty } \\
\text { days. }\end{array}$ & Rats. & $\begin{array}{l}\text { Founda significant fall in blood glucose level from } \\
381 \pm 34 \text { to } 105 \pm 35 \mathrm{mg} / \mathrm{dL} \text {. There was areduction } \\
\text { in theactivities of glucose- } 6 \text { phosphatase and } \\
\text { fructose } 1,6 \text {-bisphosphatase, and an enhancement } \\
\text { in liverhexokinaseactivity[46]. }\end{array}$ \\
\hline $\begin{array}{l}\text { Fruit } \\
\text { Pulp }\end{array}$ & $\begin{array}{l}\text { Ethanolic } \\
\text { Extract. }\end{array}$ & $\begin{array}{l}\text { Oral dose of } 300 \\
\mathrm{mg} / \mathrm{kg} / \mathrm{mL} \text { of } \\
\text { extract. }\end{array}$ & Rats. & $\begin{array}{l}\text { A swift decrease in blood glucoselevel of normal } \\
\text { fasting rats was observed[48]. }\end{array}$ \\
\hline Pulp & Ethanolic. & $\begin{array}{l}\text { Oral ingestion of } \\
300 \mathrm{mg} / \mathrm{kg} \text { of the } \\
\text { pulp. }\end{array}$ & Rats. & $\begin{array}{l}\text { Reduced blood glucose and improved the lipid } \\
\text { levels, } \\
\text { increase serum insulin AUC by } 59.5 \% \text { alongside a } \\
\text { reduction in glucose (33\%) and elsewhere this } \\
\text { extraction has been noted to increase insulin } \\
\text { content of pancreatic } \beta \text {-cells [4]. }\end{array}$ \\
\hline $\begin{array}{l}\text { Whole } \\
\text { Plant }\end{array}$ & $\begin{array}{c}\text { Aqueous } \\
\text { Extract }\end{array}$ & $\begin{array}{c}300 \mathrm{mg} / \mathrm{kg} \text { body } \\
\text { weight for twenty- } \\
\text { two days. }\end{array}$ & Rats. & $\begin{array}{l}\text { Increased blood glucose, insulin, haemoglobin, } \\
\text { HbA1C and glycogen levels in AIDrats reverted } \\
\text { back to normal level after treating withextract [40]. }\end{array}$ \\
\hline $\begin{array}{l}\text { Fruit } \\
\text { Pulp and } \\
\text { Seed }\end{array}$ & $\begin{array}{l}\text { Fruit pulp } \\
\text { as well as } \\
\text { seed } \\
\text { Extract. }\end{array}$ & $\begin{array}{l}\text { Oral administration } \\
\text { of } 100 \mathrm{mg} \text { per } \\
\text { kilogram of } \\
\text { rabbitweight. }\end{array}$ & $\begin{array}{l}\text { New Zealand } \\
\text { Rabbits. }\end{array}$ & Excellentantidiabetic results $[41]$ \\
\hline Fruits & $\begin{array}{l}\text { Petroleum } \\
\text { Ether } \\
\text { Fruits } \\
\text { Extract. } \\
\end{array}$ & $\begin{array}{l}\text { Two distinct doses } \\
(300 \text { and } 500 \mathrm{mg} / \\
\text { kg) of body wieght. }\end{array}$ & Rats. & $\begin{array}{l}\text { antidiabetic action through stimulation of } \beta \text {-cells of } \\
\text { islets of Langerhans by releasing more insulin and } \\
\text { this effect were brought about by constituents like } \\
\text { glycosides, saponins, flavonoids[45]. }\end{array}$ \\
\hline Root & $\begin{array}{l}\text { Aqueous } \\
\text { Extract. }\end{array}$ & $\begin{array}{l}\text { orally at dose level } \\
2000 \mathrm{mg} / \mathrm{kg} \text {. }\end{array}$ & Rats. & $\begin{array}{l}\text { Significant reduction in blood sugar level }(58.70 \%) \\
\text { also improvement in parameters like body weight, } \\
\text { serum creatinine, serum urea and serum protein as } \\
\text { well as lipid profile and also restored the serum } \\
\text { level of bilirubin total, conjugated bilirubin, serum } \\
\text { glutamate oxaloacetate transaminase (SGOT), } \\
\text { serum glutamate pyruvate transminase (SGPT) and } \\
\text { alkaline phosphatase (ALP)[46] }\end{array}$ \\
\hline Fruit & $\begin{array}{l}\text { Hydro- } \\
\text { Ethanol } \\
\text { extract of } \\
\text { fruit. } \\
\end{array}$ & $300 \mathrm{~g} / \mathrm{kg}$. & Rats. & $\begin{array}{c}\text { Significant decrease in the levels of total } \\
\text { cholesterol, Triglycerides, free fatty acids and } \\
\text { phospholipids in serum [42]. }\end{array}$ \\
\hline Fruits & $\begin{array}{l}\text { Aqueous } \\
\text { Extract of } \\
\text { Fruits. }\end{array}$ & $300 \mathrm{mg} / \mathrm{kg}$ & Rabbits. & $\begin{array}{l}\text { Decrease of blood glucose from } 132 \text { to } 93 \mathrm{mg} / 100 \\
\text { mL after24 h [35]. }\end{array}$ \\
\hline
\end{tabular}


Table 3: Patents granted to the researcher on Citrullus colocynthis Schrad

\begin{tabular}{|c|c|c|c|}
\hline Inventor & $\begin{array}{c}\text { Patent /Application } \\
\text { number }\end{array}$ & Summary of the invention \& References & $\begin{array}{l}\text { Date of patent/ } \\
\text { Publication }\end{array}$ \\
\hline $\begin{array}{l}\text { Liu Chong, He } \\
\text { Jiang, Yang Weijun, } \\
\text { Dili Nour Turson } \\
\text { River } \\
\text { ManharHabaHerula } \\
\text {. }\end{array}$ & CN102144491A & $\begin{array}{l}\text { A patent was granted to an inventor for his } \\
\text { invention that discloses a method for cultivating } \\
C C S \text { plants, comprising the following steps: } 1 \text {,land } \\
\text { selection: selecting inland desert or semi-desert } \\
\text { soil or semi-sandy soil with dry climate, average } \\
\text { temperature ranging from } 20 \text { DEG C to } 30 \text { DEG C } \\
\text { In May to September, and pH value of the soil } \\
\text { ranging from } 5.0 \text { to } 7.8 ; 2 \text {, seed pretreatment; } 3 \text {, } \\
\text { cultivation of treated } C C S \text { seeds: opening holes on } \\
\text { a film and directly sowing seeds, and finally } \\
\text { reserving a strong seedling in each hole; watering } \\
\text { for } 3-6 \text { tons per mu (Chinese area measurement } \\
\text { unit) at the first time around the middle of June, } \\
\text { then carrying out drip irrigation once every } 7 \text { to } 15 \\
\text { days, and totally carrying out drip irrigation } 5 \text { to } \\
12 \text { times; and harvesting during the first ten-day } \\
\text { to the middle of September. Due to the adoption of } \\
\text { the method for cultivating } C C S \text { plants, disclosed } \\
\text { by the invention, the artificial mass planting } \\
\text { cultivation of the traditional wild } C C S \text { is achieved, } \\
\text { the yield of the } C C S \text { is improved by a wide margin, } \\
\text { and the ecological environments of desert or semi- } \\
\text { desert soil or semi-sandy soil selected for the } \\
\text { artificial planting cultivation of } C C S \text { are protected } \\
\text { [43]. }\end{array}$ & 2011-08-10 \\
\hline $\begin{array}{l}\text { Hari Mohan Behl, } \\
\text { Uttar Pradesh (IN); } \\
\text { Om Prakash Sidhu, } \\
\text { Uttar Pradesh(IN); } \\
\text { Shanta Mehrotra, } \\
\text { Uttar Pradesh (IN); } \\
\text { PalpuPushpangadan } \\
\text {, Uttar Pradesh } \\
\text { (IN); } \\
\text { SaimbiCharanjit } \\
\text { Singh, Uttar } \\
\text { Pradesh (IN). }\end{array}$ & US7083779B2 & $\begin{array}{l}\text { Hari Mohan Behl from India was given an } \\
\text { approval for the patent that relates to a synergistic } \\
\text { herbal formulation comprising an active fraction } \\
\text { from AzadirachtaIndica designated as Fraction A } \\
\text { and a fraction from } C C S \text { designated as Fraction B, } \\
\text { along with a fraction } C \text { containing an antioxidant } \\
\text { from Cucumis sativus extract; and } \\
\text { pharmaceutically accepted a carrier wherein the } \\
\text { ratio of the components ranging between about } 2 \\
\text { to } 5.5 \% \text { of fraction A; about } 0.5 \text { to } 2.5 \% \text { of } \\
\text { fraction B; about } 0.1-0.4 \% \text { of extract of Cucumis } \\
\text { sativus; and about } 82-97 \% \text { of carrier or additive } \\
\text { [44]. }\end{array}$ & 2006-08-01 \\
\hline $\begin{array}{l}\text { Yang Weijun Liu } \\
\text { ChongmanHaba Dili } \\
\text { Nuer Huang Hua. }\end{array}$ & CN102138957B & $\begin{array}{l}\text { A chines scientist registered a patent on his name } \\
\text { recently in } 2013 \text { for his invention relates to a } \\
\text { colocynth extract, and a production method and } \\
\text { application thereof. The production method } \\
\text { comprises the following steps of: } \\
\text { 1, crushing colocynth fruits, and crudely } \\
\text { extracting by using water or ethanol to obtain } \\
\text { extracting solution; } \\
\text { 2, filtering and concentrating the } \\
\text { extracting solution, adding absolute ethanol, } \\
\text { placing for precipitating, and filtering precipitates } \\
\text { to obtain ethanol solution; } \\
\text { 3, concentrating the ethanol solution, regulating } \\
\text { the pH value, loading the ethanol solution to a } \\
\text { macroporous resin and/or polyamide resin layer } \\
\text { chromatography column for absorption; and } \\
4 \text {, concentrating the obtained solution, recovering } \\
\text { the ethanol, and drying to obtain the colocynth } \\
\text { extracts. } \\
\text { The inventor concludes that the production } \\
\text { method is simple and easy and has a reliable } \\
\text { process, and the obtained extract has stable } \\
\text { quality; and materials used in the production } \\
\text { process can be recycled by ethanol recovery and } \\
\text { resin regeneration, so the production cost is low, } \\
\text { and the method is suitable for industrialization }\end{array}$ & 2013-05-29 \\
\hline
\end{tabular}




\begin{tabular}{|c|c|c|c|}
\hline & & [45]. & \\
\hline $\begin{array}{l}\text { Dai Bin Miao Jing } \\
\text { Zhang Jie Zhang } \\
\text { Haiyan XieJianwei. }\end{array}$ & CN102659889A & $\begin{array}{l}\text { Another approval for a patent was given to a } \\
\text { research work "Preparation of } 23 \text {, 24-dihydro-epi- } \\
\text { iso-Cucurbitacin D and use in antitumor drug } \\
\text { thereof. The invention belongs to a natural } \\
\text { pharmaceutical chemistry field. The invention } \\
\text { mainly discloses a preparation method of } 23 \text {, 24- } \\
\text { dihydro-epi-iso-Cucurbitacin D, and use in } \\
\text { medicaments for treating tumor diseases } \\
\text { thereof.The invention belongs to a natural } \\
\text { pharmaceutical chemistry field. The invention } \\
\text { mainly discloses a preparation method of } 23 \text {, 24- } \\
\text { dihydro-epi-iso-Cucurbitacin D and a use in } \\
\text { medicaments for treating tumor diseases thereof. } \\
\text { The preparation method is recrystallizing an } \\
\text { extract of CCSin chloroform through a } \\
\text { combination of silica gel column chromatography } \\
\text { and Sephadex LH-20 column chromatography to } \\
\text { prepare } 23,24-d i h y d r o-e p i \text { isoCucurbitacin } D \text {. The } \\
23 \text {, } 24-\text {-dihydro-epi-iso-Cucurbitacin } D \text { can be used } \\
\text { as a single preparation or a combination with } \\
\text { medicinal dressing to prepare antitumor drugs for } \\
\text { treating ovarian cancer, prostatic cancer, oral } \\
\text { epidermoid cancer, and gastric cancer [46]. }\end{array}$ & 2012-09-12 \\
\hline $\begin{array}{l}\text { LamazyanGayaneR } \\
\text { achykivna ,Sereda } \\
\text { Petro Ivanovych. }\end{array}$ & UA103897U & $\begin{array}{l}\text { Recently on } 12 \text { January } 2016 \text {, A method for the } \\
\text { determination of amino acid composition of bitter } \\
\text { apple fruits by investigation of metabolism } \\
\text { disorder. Amino acid composition of bitter apple } \\
\text { fruits was determined to utilize gas-liquid } \\
\text { chromatography. Histidine, arginine, asparaginic } \\
\text { acid, serine, glutamic acid, proline, amino acetic } \\
\text { acid, alanine, cysteine, tyrosine, lysine, methionine, } \\
\text { isoleucine, leucine, and phenylalanine content } \\
\text { isdetermined and calculated in mg per } 100 \text { mg of } \\
\text { sample. This method was approved for the patent } \\
\text { [47]. }\end{array}$ & 2016-01-12 \\
\hline $\begin{array}{c}\text { Dina Ahmed Hajjar, } \\
\text { Stephan KREMB, } \\
\text { Christian } \\
\text { Voolstra, Timothy } \\
\text { Ravasi. }\end{array}$ & US20190298786A1 & $\begin{array}{l}\text { Dina Ahmed, last year in } 2019 \text { got approval for his } \\
\text { patent work of Cell-based phenotypic profiling } \\
\text { and image based high-content screening are used } \\
\text { to gain insight into the mode of action and } \\
\text { potential cellular targets of plants historically used } \\
\text { to determine anti-cancer activity of Saudi Arabian } \\
\text { plants Juniperus phoenicea (Arar), Anastatica } \\
\text { hierochuntica (Kaff Maryam), and CCS (Hanzal). } \\
\text { The cytological profiles of fractions taken from the } \\
\text { plants were compared with a set of reference } \\
\text { compounds with known modes of action. Cluster } \\
\text { analyses of the cytological profiles were } \\
\text { performed, which revealed detailed information } \\
\text { on the modes of action of the tested compounds as } \\
\text { potential topoisomerase inhibitors. Cytological } \\
\text { profiles showed that some of these compounds } \\
\text { inhibited cell proliferation causing cell cycle } \\
\text { disruption [48]. }\end{array}$ & 2019-10-03 \\
\hline
\end{tabular}

\section{CONCLUSION}

Diabetes is one of the leading causes of mortality worldwide. The conventional therapies are associated with several adverse drug reactions and require repeated administration of the medicine. Generally, natural agents, including Citrullus plants are considered to be safe while treating or preventing this disease. CCS and its different medicinal parts have potential antidiabetic activity. Some of the pharmacological properties pronounced for this plant and its 
parts are confirmed by the various examinations done in modern physiotherapy which are expressed in this paper. Among all parts, the antidiabetic action of the fruit and seed of this plant is very popular, and some in vivo and clinical trials in modern Phototherapy confirm this action. This review, have recorded the current and conventional uses of the CCS plant and its parts and summed up ongoing exploration on the antidiabetic potential of the plant parts. In view of the previously mentioned realities, patents, clinical investigations, it is obvious that the plant $C C S$ and its medicinal parts have an enormous potential for diabetes, which may reduce the mortality and prevalence rate in the world once taken into serious and novel considerations in the future.

\section{ACKNOWLEDGEMENT}

The authors are thankful to the management of Shri JJT University, Vidyanagari, Jhunjhunu, Rajasthan, India for providing the necessary facilities for this review work.

\section{REFERENCES}

[1] Zimmet, P. Z. (1999). Diabetes epidemiology as a tool to trigger diabetes research and care. Diabetologia, 42(5), 499.

[2] Pradeepa, R., \& Mohan, V. (2002). The changing scenario of the diabetes epidemic implications for India. Indian Journal of Medical Research, 116, 121.

[3] https://www.who.int/healthtopics/diabetes\#tab=tab_1
[4] Emerging Risk Factors Collaboration. (2010). Diabetes mellitus, fasting blood glucose concentration, and risk of vascular disease: a collaborative metaanalysis of 102 prospective studies. The Lancet, 375(9733), 2215-2222.

[5] Care, D. (2018). Economic Costs of Diabetes in the US in 2017. Diabetes care, $41,917$.

[6] https://professional.diabetes.org/sites/prof essional.diabetes.org/files/media/sci 2020 diabetes_fast_facts_sheet_final.pdf

[7] Levey, A. S., Coresh, J., Bolton, K., Culleton, B., Harvey, K. S., Ikizler, T. A., ... \& Levin, A. (2002). K/DOQI clinical practice guidelines for chronic kidney disease: evaluation, classification, and stratification. American Journal of Kidney Diseases, 39(2 SUPPL. 1).

[8] Levey, A. S., Stevens, L. A., Schmid, C. H., Zhang, Y., Castro III, A. F., Feldman, H. I., \& Coresh, J. (2009). A new equation to estimate glomerular filtration rate. Annals of internal medicine, 150(9), 604-612.

[9] Saran, R., Robinson, B., Abbott, K. C., Agodoa, L. Y., Bragg-Gresham, J., Balkrishnan, R., \& Gaipov, A. (2019). US renal data system 2018 annual data report: epidemiology of kidney disease in the United States. American journal of kidney diseases: the official journal of the National Kidney Foundation, 73(3 Suppl 1), A7. 
[10]Cheng, L. J., Chen, J. H., Lin, M. Y., Chen, L. C., Lao, C. H., Luh, H., \& Hwang, S. J. (2015). A competing risk analysis of sequential complication development in Asian type 2 diabetes mellitus patients. Scientific reports, 5, 15687.

[11] SAMIUN, N. A. A. B. (2017). Effects of adding a low glycaemic index diet to a carbohydrate exchange dietary advice for women with gestational diabetes mellitus.

[12] Martin, M. R., Zimmerman, R., \& Ciotto, C. (2015). Sport Nutritionist: A New Sport Education Role. Strategies, 28(3), 40-45.

[13]Jensen, M. D., Ryan, D. H., Apovian, C. M., Ard, J. D., Comuzzie, A. G., Donato, K. A., ... \& Loria, C. M. (2014). 2013 AHA/ACC/TOS guideline for the management of overweight and obesity in adults: a report of the American College of Cardiology/American Heart Association Task Force on Practice Guidelines and The Obesity Society. Journal of the American college of cardiology, 63(25 Part B), 2985-3023.

[14]Anjana, R. M., Unnikrishnan, R., Mugilan, P., Jagdish, P. S., Parthasarathy, B., Deepa, M., \& Venkatesan, U. (2018). Causes and predictors of mortality in Asian Indians with and without diabetes-10-year follow-up of the Chennai Urban Rural
Epidemiology Study (CURES-150). PloS one, 13(7).

[15] Whiting, D. R., Guariguata, L., Weil, C., \& Shaw, J. (2011). IDF diabetes atlas: global estimates of the prevalence of diabetes for 2011 and 2030. Diabetes research and clinical practice,94(3), 311-321.

[16] Anjana, R. M., Pradeepa, R., Deepa, M., Datta, M., Sudha, V., Unnikrishnan, R., \& Dhandhania, V. K. (2011). Prevalence of diabetes and prediabetes (impaired fasting glucose and/or impaired glucose tolerance) in urban and rural India: Phase I results of the Indian Council of Medical Research-India Diabetes (ICMRINDIAB) study. Diabetologia, 54(12), 3022-3027.

[17] Arvind, K., Pradeepa, R., Deepa, R., \& Mohan, V. (2002). Diabetes and coronary artery disease. IJMR, 116, 121-32.

[18] Rao, B. K., Kesavulu, M. M., Giri, R., \& Rao, C. A. (1999). Antidiabetic and hypolipidemic effects of Momordica cymbalaria Hook. fruit powder in alloxan-diabetic rats. Journal of ethnopharmacology, 67(1), 103-109.

[19] Nishikawa, T., Edelstein, D., Du, X. L., Yamagishi, S. I., Matsumura, T., Kaneda, Y. \& Giardino, I. (2000). Normalizing mitochondrial superoxide production blocks three pathways of hyperglycaemic damage. Nature, 404(6779), 787-790. 
[20] Irshaid, F., Mansi, K., \&Aburjai, T. (2010). Antidiabetic effect of essential oil from Artemisia sieberi growing in Jordan in normal and alloxan induced diabetic rats.Pakistan Journal of Biological Sciences, 13(9), 423.

[21]Dallak, M., \& Bin-Jaliah, I. (2010). Antioxidant activity of citrullus colocynthis pulp extract in the rbcâ€ $€^{\mathrm{TM}} \mathrm{s}$ of alloxan-induced diabetic rats. Pakistan journal of Physiology, 6(1), 1-5.

[22] Jongbloed, M., Feulner, G., Böer, B., \& Western, A. R. (2003). The comprehensive guide to the wild flowers of the United Arab Emirates. Environmental Research and Wildlife Development Agency.

[23]Lloyd, J. U., \& Cincinnati, O. (1898). Citrullus colocynthis. Engelhard.

[24] Rahimi, R., Amin, G., \&Ardekani, M. R. S. (2012). A review on Citrullus colocynthisSchrad.: from traditional Iranian medicine to modern phytotherapy. The journal of alternative and complementary medicine, 18(6), 551-554.

[25] Shahabi, S., Hassan, Z. M., Mahdavi, M., Dezfouli, M., Rahvar, M. T., Naseri, M., ... \&Khalkhali, H. R. (2008). Hot and Cold natures and some parameters of neuroendocrine and immune systems in traditional Iranian medicine: a preliminary study. The Journal of
Alternative

and

Complementary Medicine, 14(2), 147-156.

[26]Heravi, M. (1992). Alabnya an alHaghayegh al-Advia. Tehran, Iran: Tehran University.

[27] Shahid, M., \& Rao, N. K. (2014). Diversity of Citrullus colocynthis (L.) Schrad. (Cucurbitaceae) in the United Arab Emirates. Journal on New Biological Reports, 3(2), 145-150.

[28] Tonkaboni, M. M. (2007). Tohfeh almomenin. Tehran: Shahid Beheshti University of Medical Sciences.

[29] Rahimi, R., Amin, G., \&Ardekani, M. R. S. (2012). A review on Citrullus colocynthis Schrad:: from traditional Iranian medicine to modern phytotherapy. The journal of alternative and complementary medicine, 18(6), 551-554.

[30] Dalfardi, B., \& Yarmohammadi, H. (2014). The heart under the lens of Avicenna. International journal of cardiology, 173(1), e1-e2.

[31]Hussain, A. I., Rathore, H. A., Sattar, M. Z., Chatha, S. A., Sarker, S. D., \& Gilani, A. H. (2014). Citrullus colocynthis (L.) Schrad (bitter apple fruit): A review of its phytochemistry, pharmacology, traditional uses and nutritional potential. Journal of ethnopharmacology, 155(1), 54-66.

[32] Pravin, B. (2013). Review on Citrullus colocynthis/Borahade Pravin, Dechmukh 
Tushar, Patil Vijay at all. International Journal of Research in Pharmacy and Chemistry, (3), 1.

[33]Hussain, A. I., Rathore, H. A., Sattar, M. Z., Chatha, S. A., Sarker, S. D., \& Gilani, A. H. (2014). Citrullus colocynthis (L.) Schrad (bitter apple fruit): A review of its phytochemistry, pharmacology, traditional uses and nutritional potential. Journal of ethnopharmacology, 155(1), 54-66.

[34]Meena, M. C., Meena, R. K., \& Patni, V. (2014). Ethnobotanical studies of Citrullus colocynthis (Linn.) Schrad. An important threatened medicinal herb. Journal of Medicinal Plants, 2(2), $15-22$.

[35]Bande, Y. M., Adam, N. M., Jamarei, B. O., Azmi, Y., \& Razali, S. Z. (2013). Examining the physicochemical properties and engine performance of biodiesel from whole seed and extracted kernels of egusi (Citrullus lanatus). ScienceAsia, 39(5), 492-499.

[36] Aviara, N. A., Shittu, S. K., \& Haque, M. A. (2007). Physical properties of guna fruits relevant in bulk handling and mechanical processing. International Agrophysics, 21(1), 7.

[37] Marzouk, B., Marzouk, Z., Fenina, N., Bouraoui, A., \&Aouni, M. (2011). Antiinflammatory and analgesic activities of Tunisian Citrullus colocynthisSchrad. immature fruit and seed organic extracts. Eur Rev Med Pharmacol Sci, 15(6), 665-72.

[38] Kumar, P., Singh, A., Sharma, U., Singh, D., Dobhal, M. P., \& Singh, S. (2013). Anti-mycobacterial activity of plumericin and isoplumericin against MDR Mycobacterium tuberculosis. Pulmonary pharmacology \& therapeutics, 26(3), 332-335.

[39] Schafferman, D., Beharav, A., Shabelsky, E., \& Yaniv, Z. (1998). Evaluation ofCitrulluscolocynthis, a desert plant native in Israel, as a potential source of edible oil. Journal of Arid Environments, 40(4), 431-439.

[40] Chawech, R., Jarraya, R., Girardi, C., Vansteelandt, M., Marti, G., Nasri, I., ... \& Fabre, N. (2015). Cucurbitacins from the leaves of Citrullus colocynthis (L.) Schrad. Molecules, 20(10), 18001-18015.

[41] Meena, M. C., \& Patni, V. (2008). Isolation and identification of flavonoid "quercetin" from Citrullus colocynthis (Linn.) Schrad. Asian J Exp Sci, 22(1), 137-142.

[42] Najafi, S., Sanadgol, N., Nejad, B. S., Beiragi, M. A., \&Sanadgol, E. (2010). Phytochemical screening and antibacterial activity of Citrullus colocynthis (Linn.) Schrad against Staphylococcus aureus. $J$ Med Plants Res, 4(22), 2321-5.

[43] Sagar, R., Dumka, V. K., Kaur, R., \& Singla, S. (2018). Evaluation of anti- 
inflammatory, antibacterial and acaricidal activities of various leaf extracts of Pongamiapinnata. Journal

Pharmacognosy and

Phytochemistry, 7(1), 2464-2467.

[44]Tannin-Spitz, T., Grossman, S., Dovrat, S., Gottlieb, H. E., \& Bergman, M. (2007). Growth inhibitory activity of Cucurbitacin glucosides isolated from Citrullus colocynthis on human breast cancer cells. Biochemical pharmacology, 73(1), 56-67.

[45] Milovanović, M., \&Pićurić-Jovanović, K. (2005). Characteristics and composition of melon seed oil. Journal of Agricultural Sciences (Belgrade), 50(1), 41-47.

[46] Rahimi, R., Amin, G., \&Ardekani, M. R. S. (2012). A review on Citrullus colocynthisSchrad.: from traditional Iranian medicine to modern phytotherapy. The journal of alternative and complementary medicine, 18(6), 551-554.

[47] Sadou, H., Sabo, H., Alma, M. M., Saadou, M., \& Leger, C. L. (2007). Chemical content of the seeds and physico-chemical characteristic of the seed oils from Citrullus colocynthis, Cocciniagrandis, Cucumis metuliferus and Cucumis prophetarum of Niger. Bulletin of the Chemical Society of Ethiopia, 21(3), 323-330.
[48] Sebbagh, N., Cruciani-Guglielmacci, C., Ouali, F., Berthault, M. F., Rouch, C., Sari, D. C., \& Magnan, C. (2009). Comparative effects of Citrullus colocynthis, sunflower and olive oilenriched diet in streptozotocin-induced diabetes in rats. Diabetes \& metabolism, 35(3), 178-184.

[49] Kalhoro, M. A., Afza, N., Saleem, M., \& Malik, A. (2002). Pharmacochemical studies of the oil, aerial parts, pulp and peel of Citrullus colocynthis. Journal of the Chemical Society of Pakistan, 24(4), 274-276. 